\title{
Young people and mountain
}

Evidence from a survey in the Northern Italy

\section{Andrea Macchiavelli et Andrea Pozzi}

\section{(2) OpenEdition}

Journals

Édition électronique

URL : https://journals.openedition.org/rga/2392

DOI : $10.4000 /$ rga.2392

ISSN : $1760-7426$

Traduction(s) :

I giovani e la montagna - URL : https://journals.openedition.org/rga/2397 [it]

Éditeur :

Association pour la diffusion de la recherche alpine, UGA Éditions/Université Grenoble Alpes

Référence électronique

Andrea Macchiavelli et Andrea Pozzi, «Young people and mountain », Journal of Alpine Research 1 Revue de géographie alpine [En ligne], 102-4 | 2014, mis en ligne le 03 août 2014, consulté le 08 décembre 2022. URL : http://journals.openedition.org/rga/2392; DOI : https://doi.org/10.4000/rga 2392

Ce document a été généré automatiquement le 8 décembre 2022.

\section{c) (i) $($ ) $९$}

Creative Commons - Attribution - Pas d'Utilisation Commerciale - Pas de Modification 4.0 International - CC BY-NC-ND 4.0

https://creativecommons.org/licenses/by-nc-nd/4.0/ 


\title{
Young people and mountain
}

\author{
Evidence from a survey in the Northern Italy \\ Andrea Macchiavelli et Andrea Pozzi
}

1 Recent tourism trends shows that holidays in mountain destinations are decreasing. This fact is partly linked with the current economic conditions because demand for mountain holidays is mainly domestic and crisis have affected especially this market (Macchiavelli, 2014). However, it can be largely viewed as a result of the long-term process concerning the decreasing appeal of mountain areas and the strong competition with other types of tourism. Especially younger generations have gradually lost their interest in mountain and, consequently, their behaviour during holidays has changed over time. This fact has been highlighted for the first time more than twenty years ago (Bourdeau, 1991); in the following years changes in behaviour continued in new directions but they have become more difficult to notice and classify, as the survey on French population carried out by COFREMCA has shown (Atout France, 2011). For these reasons the knowledge of young people behaviour in mountain areas appears to be relevant to understand tourism trends and, consequently, to address future tourism policies of alpine destinations.

\section{Literature Review}

2 The issue of collecting information regarding number and characteristics of visitors in mountain areas raises several problems connected with the dimension of the area under investigation and the period of visits. At present statistical data are lacking; only data on tourists in mountain huts are available and may be useful for this issue, but the number is usually underestimated.

3 As concern for Italy, until the mid-1990s the knowledge has been fragmented and incomplete; researches on this issue has focused on recreational use of forests, considering also mountain areas (Tosi, Scrinzi, 1994). At present there are some researches focusing on the alpine areas, which has been carried out in Veneto (Tempesta, Thiene, 2001; Scarpa, Tempesta, Thiene, 2007), Friuli Venezia Giulia 
(Assorifugi, Irtef, 1997 cit. in Matto, 2004; Marangon, Gottardo, 2001; Marangon et al., 2002) and Piedmont (Matto, 2004; Dondona, 2009).

4 International literature reports recent researches regarding this topic (Godde, Price, Zimmermann 2000; Lynn, Brown, 2003; Chhetri, Arrowsmith, Jackson, 2004); however, they focus mainly on the relationship between the practice of hiking and natural landscape. Other researches consider a wide range of outdoor activities, but very few are alpine. This kind of activities has been considered mainly in French, German and Italian researches (Atout France, 2012; FISI, 2011).

\section{Data and Methodology}

5 Data used in this paper have been collected and analysed during an extensive research carried out for ERSAF ${ }^{1}$ in the INTERREG project named VETTA ${ }^{2}$. This project has also aimed at deepening knowledge on the relationship between people and mountain and it has also paid a great attention on younger generations.

6 Analysis considers only people living in Northern Italy, Lombardy in particular; the research project consists in three surveys with different techniques:

- A direct CATI survey ${ }^{3}$ on a population sample in order to analyse perception, visit and sport practice in alpine areas among residents of Northern Italy ${ }^{4}$. The survey was carried out in April 2011 on a proportional sample (balanced on region of residence, gender and age) of 2,285 persons (representativeness of the sample: 95\%; maximum margin of error: 1,83\%). The results are representative of the regions involved - not of the entire Italian population and give important information on people's behaviour-in mountain areas in relation to the age and, therefore, also on young people.

- A direct survey based on a cluster sample of 17 upper secondary schools (940 students of the fourth and fifth year) in the provinces of Milano, Lecco and Sondrio ${ }^{5}$ in order to investigate the relationship between young people and recreational use of mountain areas. The survey was carried out from February to May 2012. All the students involved were invited to complete an online questionnaire. The first part contained multiple-choice questions; the aim was to investigate the interest of students in mountain areas (especially the practice of sports) and its origin. The second part of the questionnaire was only for students who usually visit mountain areas. In order to assess young people's preferences for mountain activities, this part used conjoint analysis technique.

- Focus groups and in-depth interviews with instructors, guides and operators from the Club Alpino Italiano (CAI) in order to investigate the role of the organization in promoting mountains and mountain sports (e.g. hiking). Many of these interviews have been conducted with members of the Youth Mountaineering Commissions. The survey has been carried out in June 2012. Thirty members from 3 local branches in Lombardy (Milano, Lecco and Sondrio, the same provinces considered in the previous survey) have been involved in 3 focus groups. The president or vice-president of each local branch has been interviewed.

7 We decide to summarize the great amount of information by 4 main topics: the attractiveness of mountain destinations ("Mountain as a tourist attraction"); the habit of visiting mountain ("The cultural dimension of visiting mountain"); the role of associations in stimulating people to go to mountains ("Mountain sports as opportunities to get together"); most popular sports and activities among practitioners ("Mountain as a space to live: the activities"). 


\section{Mountain as a tourist attraction}

The results show that mountain arouses positive emotions, also among young people under 24 years of age: $34 \%$ of them associate beauty with mountain, while $51 \%$ the sense of freedom. Negative emotions such as boredom/indifference and risk are not usually associated with mountain (respectively $11 \%$ and $4 \%$ ). Gender partly influences the perception of mountain: girls tend to be more susceptible to effort and risk than boys.

Different results have been registered among the entire population: $51 \%$ associates beauty with mountain while $35 \%$ the sense of freedom. We therefore notice a slightly different perception of mountain, because young people tend to be more susceptible to freedom than beauty. Graph 1. Difference in perception of mountain between the entire population and young people
under 24 years of age, \%

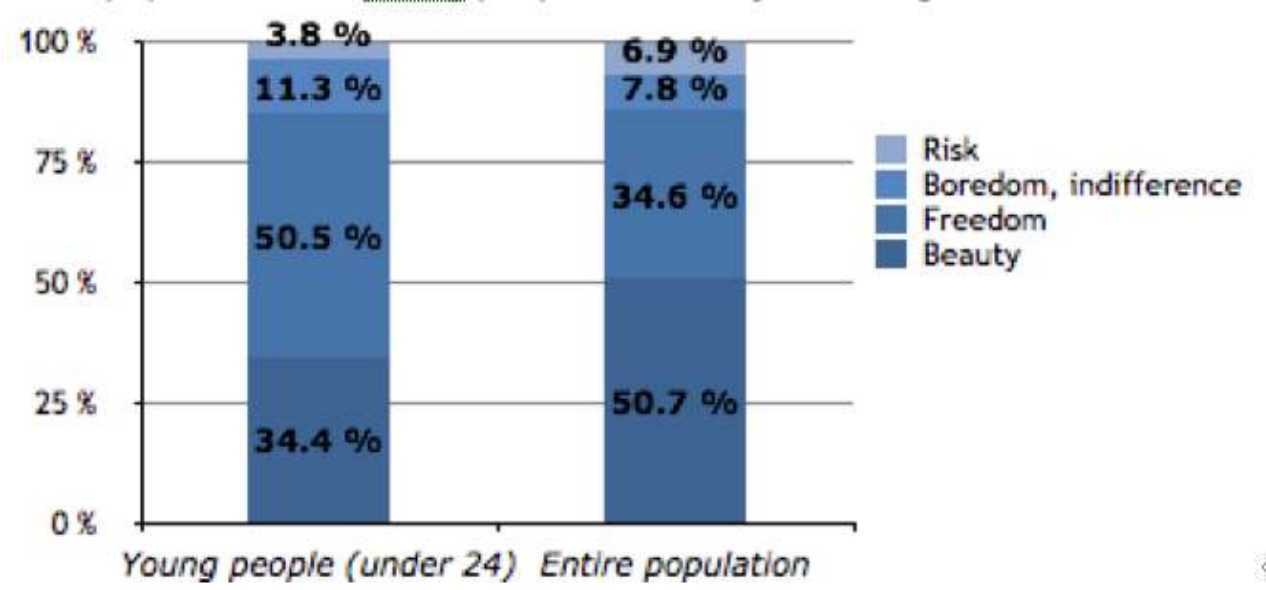

10 As concern the perception of sport practice in mountain, amusement and beauty of the landscape represent the most frequently answers. However, young people tend to associate sport practice with amusement more often than population (respectively $40 \%$ and $28 \%)$; beauty is common in both groups (32,5\% and $49 \%)$. It is also important to notice that the idea of self-affirmation is quite popular among young $(7,5 \%$, while only $4,6 \%$ in the entire population).

Moreover, the results show that:

- as for the perception of mountain, the beauty increase with age while the sense of freedom tends to decrease; risk is not correlated with age.

- as for the perception of sport practice, amusement decrease with age while self-affirmation tend to increase; the perception of effort is higher in young and old people; finally, risk is not correlated with age.

12 As shown above, beauty of mountain landscape is the main factor of attraction not only for older generations but also for many young people. Also other international researches on the same topics (Atout France, 2011, p.19 and following) have highlighted that tourists and visitors are greatly influenced by mountain landscape.

Visiting alpine areas is a very common practice in Northern Italy: 67\% make daily excursion or go on holiday, but only $23 \%$ do alpine sports. As concern young people we 
notice better results (respectively $75 \%$ and $43 \%$ ). There's a great interest in mountain also among students from upper secondary schools in Lombardy: about $60 \%$ of visitors usually practice and one third of non-visitor respondents is willing to do some sports. However, we must consider that the survey on students has been carried out even in two mountain provinces - Sondrio and Lecco - where alpine sports are common.

Graph 2. Difference in visiting mountain areas between the entire population and young people under 24 years of age, \%

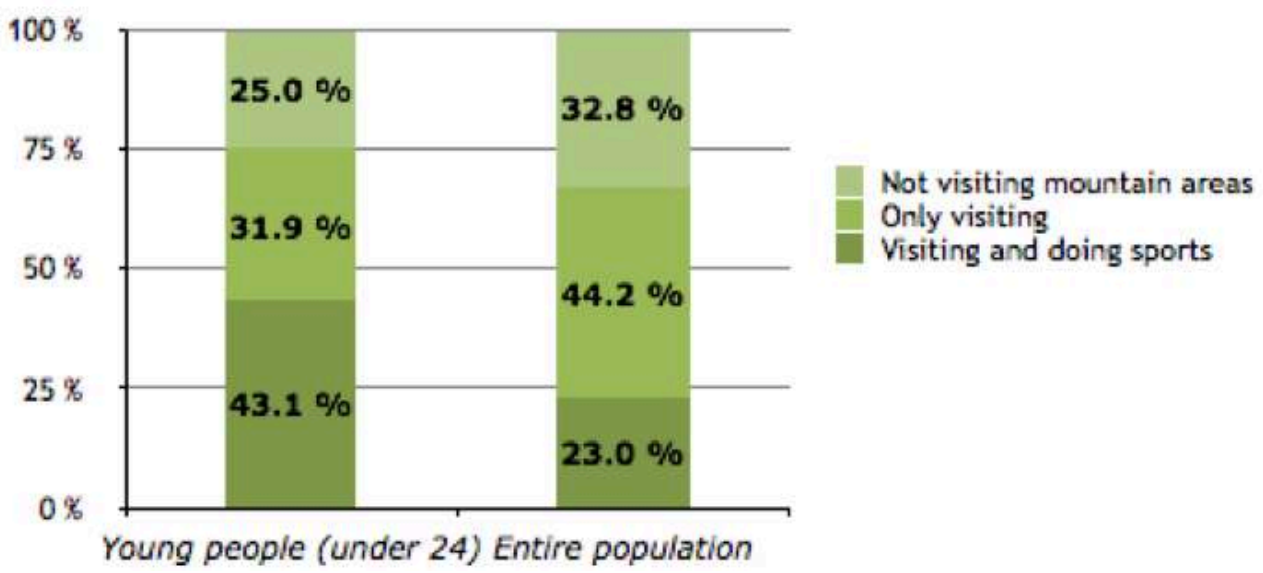

14 Alpine sports are more common among young people with higher education. Those who do not practice have been negatively influenced mainly by "not being introduced" (49\%) and secondly by the perception of the effort (22\%). Reversed results have been observed in the entire population.

The main reasons for doing alpine sports among young people are amusement (42\%) and company (25\%). The same reasons are less significant considering the entire population; actually, older generations are more susceptible to relax and physical fitness. The survey also shows no great differences between the 3 provinces involved; that probably means homogeneity of behaviours in recreational use of mountain areas among young people (Warde, Tampubolon, 2002).

Table 1. Reasons for doing sports among young people and the entire population, \% (sample size: 531)

\begin{tabular}{|l|l|l|}
\hline & Young people (under 24) & Entire population \\
\hline Amusement & $42.0 \%$ & $28.8 \%$ \\
\hline Relax & $14.5 \%$ & $28.6 \%$ \\
\hline Company & $24.6 \%$ & $15.3 \%$ \\
\hline Physical fitness & $11.6 \%$ & $14.7 \%$ \\
\hline Beauty of the landscape & $7.2 \%$ & $12.6 \%$ \\
\hline
\end{tabular}


Table 2. Reasons for not doing sports among young people and the entire population, \% (sample size: 1,022)

\begin{tabular}{|l|l|l|}
\hline & Young people (under 24) & Entire population \\
\hline Effort & $21.6 \%$ & $42.3 \%$ \\
\hline Not being introduced & $49.0 \%$ & $24.9 \%$ \\
\hline High price & $11.8 \%$ & $14.5 \%$ \\
\hline Risk & $9.8 \%$ & $13.5 \%$ \\
\hline No answer & $7.8 \%$ & $4.9 \%$ \\
\hline
\end{tabular}

16 Finally, results show that young people is still attracted by mountain destinations; however, they're mainly interested in a place where they can be free and have fun without too much effort. On the other hand, those who do not practice complain a lack of opportunities. Similar facts have been highlighted in a French research carried out in 2001, which also affirms that mountain destinations have difficulties in transforming people attracted to mountain into tourists; the same trend has been observed also among young people (Atout France, 2011, p. 26 and 49).

The popularity of sport practice observed in this analysis cannot be viewed as consequence of the habit of visiting mountain areas; actually, although they are attractive, they only represent one of the places where do sport or have a trip occasionally.

\section{The cultural dimension of visiting mountain}

18 The habit of visiting mountain areas may be considered a cultural dimension. The survey on residents of Northern Italy has highlighted two factors that influence this habit: family environment and geographical proximity to home. This habit has been investigated more deeply in the survey on students from upper secondary schools in Lombardy that has considered also mountainous areas (provinces of Lecco and Sondrio).

19 Results show firstly that visiting mountain areas is highly influenced by family environment. Among students from Lombardy, an average of 3 in 4 (75\%) have begun to go with their own family under 7 years of age. This percentage rises considering only mountainous provinces: for example, $90 \%$ of those living in the province of Sondrio have begun to go when they were children. On the contrary, who are willing to go have been on mountain for the first time later, often with some youth organization such as CAI and scouts. Family environment has therefore a great impact on the habit of visiting mountain. In fact, the Alps have been often the favourite destination for these families, which usually have second homes in these areas. 
Table 3. Starting age of visiting mountain among students from upper secondary schools in Lombardy (provinces of Milano, Lecco and Sondrio), \% (sample size: 941)

\begin{tabular}{|l|l|l|l|l|}
\hline & Total & Milano & $\begin{array}{l}\text { Lecco } \\
\text { (partly mountainous) }\end{array}$ & $\begin{array}{l}\text { Sondrio } \\
\text { (entirely mountainous) }\end{array}$ \\
\hline Under 8 & 73,9 & 60,0 & 73,3 & 87,8 \\
\hline 8 - 13 years & 18 & 25,5 & 18,8 & 10,1 \\
\hline Over 13 & 5,5 & 9,4 & 6,3 & 1,2 \\
\hline Never visiting mountain & 2,1 & 4,8 & 1,7 & 0 \\
\hline Not indicated & 0,4 & 0,3 & 0,0 & 0,9 \\
\hline TOTAL & 100,0 & 100,0 & 100,0 & 100,0 \\
\hline
\end{tabular}

Also geographical proximity influences the habit of visiting mountain areas, especially number of visits and length of stay. In the mountain province of Sondrio, for example, $80 \%$ of students visit mountain; otherwise, in the non-mountain province of Milano (which is not too far from the Alps) this percentage is only $46 \%$.

21 As regards the length of stay, the behaviour observed in young people and among residents of Northern Italy is similar. The only difference is that young people tend to prefer weekend to daily excursion and long holiday. The survey also shows that there's no specific preference; however, the number of daily excursions tend to increase in the areas closer to the Alps, as noticed in other similar researches carried out in the Northeast Italy (Scarpa, Thiene, Tempesta, 2007).

Family environment and geographical proximity appear to be strictly linked and, therefore, they can be considered a unique cultural factor that contributes to pass down the alpine culture. COFREMCA survey on French population comes to a similar conclusion affirming that "La mer est naturelle, c'est de la culture d'aller à la montagne" ("Sea is natural while visiting mountain requires a culture") (Atout France, 2011, p. 51).

\section{Mountain sports as opportunities to get together}

The CATI survey has shown that the need of being with someone is one of the main reasons for doing alpine sports. Young people practice both in winter and summer mainly with family or friends (93\%); practicing alone (6\%) and going with association (1\%) are not common. Similar results have been observed among students from Lombardy; in this case the percentage is $\mathbf{3 - 4 \%}$. However, the sample includes only young people from secondary upper schools (aged 17-19 years) and the survey considers mountainous provinces, where these percentages obviously decrease.

Both surveys highlight that young people tend to prefer associations different from Club Alpino Italiano (CAI); this result has not been observed among the entire population (see Table 4). 
Table 4. Type of groups chosen in mountain trips, \%

\begin{tabular}{|l|l|l|l|}
\hline & $\begin{array}{l}\text { Practitioners in } \\
\text { Northern Italy }\end{array}$ & $\begin{array}{l}\text { Only young practitioners } \\
\text { (under 24) in Northern Italy }\end{array}$ & $\begin{array}{l}\text { Students from upper } \\
\text { secondary schools in } \\
\text { Lombardy }\end{array}$ \\
\hline Alone & 6.4 & 5.8 & 4.1 \\
\hline $\begin{array}{l}\text { With family and } \\
\text { friends }\end{array}$ & 89.5 & 92.8 & 90.5 \\
\hline $\begin{array}{l}\text { With Club Alpino } \\
\text { Italiano }\end{array}$ & 2.4 & 0 & 1.3 \\
\hline $\begin{array}{l}\text { With other } \\
\text { associations }\end{array}$ & 1.5 & 1.4 & 3.0 \\
\hline No answer & 0.2 & & 1.1 \\
\hline
\end{tabular}

This trend is quite alarming: youth associations are less popular today than in the past, especially those concerning mountain; this fact may negatively influence the spread of the culture of mountain among young people and therefore their attitude toward visiting mountain areas regularly. Today also religious organizations such as Parishes tend to be less interested in mountain while in the past they have usually offered summer holidays on mountain. Mainly during focus groups in the local branches of Club Alpino Italiano (CAI) the operators have highlighted this alarming trend, although they always pay a great attention in youth activities. Moreover, they have pointed out that parents prefer that their children become members of Club Alpino Italiano not for the desire to belong to the association but for issues concerning safety in mountain.

Nowadays the role of the Club Alpino Italiano in involving people in mountain sports is less important than in the past; for example, the daily excursions with bus organized by CAI has been replaced, in many places, with self-organized trips by car. The organization is still an important centre for alpine culture and offers to its members many opportunities (e.g. training courses) and facilities (e.g. insurance). Actually, people who intend to engage in hiking or mountaineering learn tips and techniques and have a travel insurance prefer to become a member of CAI.

During the focus groups we also noticed different profile and behaviour between members of non-mountain (Milano) and mountain branches (Lecco and Sondrio). People from Milano participate at excursion with bus in order to go hiking in company and meet new people; they're often workers and students temporarily in the city. In this case, bus can be considered a means for socialization. Members from mountain branches, by contrast, know each other very well; daily excursion is an occasion to go hiking or mountaineering with friends, usually using their car. 


\section{Mountain as a space to play: the activities}

Since mountain is still attractive for young people mainly because it is a place to practice sports, have fun and be free, it is important to analyse most practiced sports and to compare these results with those registered among the entire population. As Graph 2 has shown, there are more non-practitioners ${ }^{6}$ in the residents of Northern Italy than among young people (respectively $44,1 \%$ and $31,9 \%$ ).

The main result of the analysis on mountain sports is the variety of ways to enjoy mountain areas actively; obviously, young people's behavior has a great influence on this. Table 5 shows most practiced summer sports among three groups of people: practitioners in Northern Italy, young practitioners in Northern Italy under the age of 24 years and students from upper secondary school in Lombardy.

Table 5. Alpine summer sports participation rates, summer 2010, $\%$

\begin{tabular}{|l|l|l|l|}
\hline & $\begin{array}{l}\text { Practitioners } \\
\text { Northern Italy }\end{array}$ & $\begin{array}{l}\text { Only young practitioners (under } \\
\text { 24) in Northern Italy }\end{array}$ & $\begin{array}{l}\text { Students from upper secondary } \\
\text { schools in Lombardy }\end{array}$ \\
\hline $\begin{array}{l}\text { Hiking } \\
\text { (duration }<4 \\
\text { h) }\end{array}$ & 79,7 & 71,0 & 87,4 \\
\hline $\begin{array}{l}\text { Hiking } \\
\text { (duration }>4 \\
\text { h) }\end{array}$ & 55,6 & 43,5 & 52,4 \\
\hline $\begin{array}{l}\text { Mountain } \\
\text { Biking }\end{array}$ & 23,7 & 27,5 & 32,2 \\
\hline $\begin{array}{l}\text { Climbing } \\
\text { Other } \\
\text { activities }\end{array}$ & 7,0 & 7,2 & 20,0 \\
\hline
\end{tabular}

Results also show that:

- Hiking is the most common summer sport: about $80 \%$ of practitioners go for a hike; however, many people (especially young) tend to limit physical effort in outdoor activities: the duration of the trip is more than 4 hours $^{7}$ in only $55,6 \%$ of cases; this percentage decrease to $43,5 \%$ considering only young practitioners.

- Traditional summer sports (hiking and climbing) are less popular among young people, which tend to do other activities.

- Young practitioners are more attracted to new ways to enjoy mountain areas actively. The results also show that Mountain Biking is the second most common summer sport: 1 in 4 (25\%) of practitioners and 1 in 3 (33\%) of students go mountain biking. This sport has recently moved to a mainstream activity in many alpine areas, as observed also in other analysis (Saint-Martin, J. Savre F., Terret T., 2013); its popularity is therefore increasing the need for dedicated trails and bicycle rental facilities (Pickering, Rossi, Barros, 2011). 
- Young people tend to practice less strenuous activities such as long hikes (duration $>4 \mathrm{~h}$ ) and climbing than average.

- Living in mountainous areas positively influence participation rates, also in traditional summer sports.

Finally, people who often go to mountains are more interested in traditional activities while who live far from these areas seem to be more attracted to new sports. Mountain Biking is the most popular summer activity among young people after hiking. Many alpine destinations are going to open new Bike Parks, which also allow opening chairlifts in summer and keeping the area profitable. For example, during summer season the Dolomiti Superski Consortium (a well-known ski resort) offers a great variety of MTB trails in the Dolomite area and an easy access to the lift through the Dolomiti Summer Card.

Table 6 shows the number of days dedicated to summer alpine sport practice. The results suggest that:

- Young people tend to do less strenuous activities and practice occasionally. In fact the incidence rates referring to regular sport practice (more than 10 days per year) are lower than the average registered in the entire population.

- Mountain Biking registers highest participation rates among younger generations with the exception of the category "more than 20 days". This fact may be considered the proof of what highlighted above, although Mountain Biking is increasing its popularity in young people.

Table 6. Days dedicated to alpine sport practice in summer 2010 among young people and the entire population, \%

\begin{tabular}{|c|c|c|c|c|c|c|c|c|c|c|}
\hline & $\begin{array}{l}\text { Hiking } \\
\text { hours }\end{array}$ & $<\quad 4$ & $\begin{array}{l}\text { Hiking } \\
\text { hours }\end{array}$ & $>\quad 4$ & MTB & & Climbi & & $\begin{array}{l}\text { Other } \\
\text { activit }\end{array}$ & \\
\hline & Young & Total & Young & Total & Young & Total & Young & Total & Young & Total \\
\hline None & 29.0 & 20.3 & 56.5 & 44.4 & 72.5 & 76.3 & 92.8 & 87.6 & 89.9 & 93,0 \\
\hline From 1 to 10 & 65.2 & 60.2 & 40.6 & 43.1 & 18.8 & 14.9 & 5.8 & 9.8 & 7.2 & 5,5 \\
\hline $\begin{array}{l}\text { From } 11 \text { to } \\
20\end{array}$ & 5.8 & 11.7 & 1.4 & 6.2 & 8.7 & 4,1 & 1.4 & 1.5 & 2.9 & 0,8 \\
\hline More than 20 & 0 & 7.8 & 0 & 5.8 & 0 & 4,7 & 0 & 1.1 & 0 & 0,8 \\
\hline No answer & & & 0.4 & 1.4 & & & & & & \\
\hline
\end{tabular}

As concern young people's preferences for hiking, we observe interests and behaviours different for mountain areas. The survey on students from upper secondary schools shows that there are two main groups: the first one considers alpine sports as soft activities to practice during a relaxing holiday; the second - and smaller - one is more interested in demanding sports.

Table 7 shows the participation rates of winter alpine sports among the same three groups (practitioners in Northern Italy, young practitioners in Northern Italy under the 
age of 24 years and students from upper secondary school in Lombardy). Alpine skiing is still the most popular winter sport; in fact 1 in $2(51 \%)$ of practitioners goes skiing. The participation rate is higher among young people (68\%) but they tend to practice occasionally. Moreover, it is important to remember that nowadays many tourists in alpine winter destinations practice no sports, preferring other activities such as relaxation, shopping and wellness. Tourist demand shows therefore a great interest in a wide range of activities; among them, alpine skiing is the most popular winter sport, even is declining.

Table 7. Alpine winter sports participation rates, winter $\mathbf{2 0 1 0} \%$

\begin{tabular}{|l|l|l|l|}
\hline & $\begin{array}{l}\text { Practitioners in } \\
\text { Northern Italy }\end{array}$ & $\begin{array}{l}\text { Only young practitioners } \\
\text { (under 24) in Northern Italy }\end{array}$ & $\begin{array}{l}\text { Students from upper } \\
\text { secondary schools in } \\
\text { Lombardy }\end{array}$ \\
\hline Alpine skiing & 50.8 & 68.1 & 39.3 \\
\hline $\begin{array}{l}\text { Ski } \\
\text { mountaineering }\end{array}$ & 25.0 & 27.5 & 9.6 \\
\hline Snowshoeing & 21.7 & 17.4 & 14.7 \\
\hline $\begin{array}{l}\text { Cross-country } \\
\text { skiing }\end{array}$ & 18.1 & 14.5 & 13.1 \\
\hline Snowboarding & 9.4 & 27.5 & 19.8 \\
\hline Other Activities & 18,5 & 14.5 & 6.4 \\
\hline
\end{tabular}

The results confirm that people do many sports, often without regularity ("zapping"), as observed in similar analysis (FISI 2011). Older adults often practice snowshoeing, especially who is over 60 years (30\%); similar data have been observed in a survey carried out in Alto Adige by ASTAT (2010). On the other hand snowboarding is very popular among young people, although the participation to this sport will not probably increase in future. In France, for example, in winter 2007/08 about 12\% of practitioners snowboarded (Odit France, 2009). Finally cross-country skiing is declining, especially among young people.

At the beginning of 2000s winter sports were different from those practiced during the 80 s. The change had been so deep that it had called into question the entire tourist offer of ski resorts (Bourdeau, 2007). This process is still going on, but some sport activities have reached their maturity and market segments are now well defined. This induces to increase the attention for the quality of tourist offer, which is not a simple mix of sports and recreational activities for young people but a unique and coherent product including services, events and proposals made for younger generations. For example, Mottolino ski area ${ }^{8}$ - which is located near Livigno (So, Italy) - has adjusted its winter and summer offer paying special attention to young people; the area is equipped to practice sports such as Mountain Biking or snowboarding and events, bars and also music are mainly for young people. 
Table 8 confirm that young practitioners consider winter sports as an entertainment and tend to practice them occasionally. This fact is evident for all the activities, with the exception of sports less interesting for young people such as snowshoeing and cross-country skiing. For example, only 3 in 100 snowboard more than 10 days per year.

Table 8. Days dedicated to alpine sport practice in winter 2010 among young people and the entire population, \%

\begin{tabular}{|c|c|c|c|c|c|c|c|c|c|c|c|c|}
\hline & \multicolumn{2}{|l|}{$\begin{array}{l}\text { Alpine } \\
\text { skiing }\end{array}$} & \multicolumn{2}{|c|}{$\begin{array}{l}\text { Ski } \\
\text { mountaineering }\end{array}$} & \multicolumn{2}{|c|}{ Snowshoeing } & \multicolumn{2}{|c|}{$\begin{array}{l}\text { Cross- } \\
\text { country } \\
\text { skiing }\end{array}$} & \multicolumn{2}{|c|}{ Snowboarding } & \multicolumn{2}{|c|}{$\begin{array}{l}\text { Other } \\
\text { activities }\end{array}$} \\
\hline & Young & Total & Young & Total & Young & Total & Young & Total & Young & Total & Young & Total \\
\hline None & 31.9 & 49.2 & 73.9 & 75.0 & 82.6 & 78.3 & 85.5 & 81.9 & 72.5 & 90.6 & 85.5 & 81.5 \\
\hline $\begin{array}{l}\text { From } \\
1 \text { to } \\
10\end{array}$ & 58.0 & 37.1 & 23.2 & 19.8 & 15.9 & 18.8 & 14.5 & 15.3 & 24.6 & 7.5 & 14.5 & 14.7 \\
\hline $\begin{array}{l}\text { From } \\
11 \text { to } \\
20\end{array}$ & 5.8 & 9.2 & 2.9 & 3.6 & 1.4 & 1.7 & 0 & 1.1 & 2.9 & 0 & 0 & 1.1 \\
\hline $\begin{array}{l}\text { More } \\
\text { than } \\
20\end{array}$ & 4.3 & 4.5 & 0 & 1.7 & 0 & 1.1 & 0 & 1.7 & 0 & 0 & 0 & 2.6 \\
\hline
\end{tabular}

As concern alpine skiing, it is important to notice that its popularity among young people is not decreasing; the participation rates are even higher than those registered in the entire population. However, young people practice occasionally and without regularity. This has brought to a decrease in ski sales in Italy: in the last ten years sales volume have halved (data from Pool Sci Italia ${ }^{9}$ ) and ski rental has turned to be a great alternative to purchase, becoming very popular.

\section{Conclusions}

Starting from the great amount of data and information collected ${ }^{10}$, we can highlight the most important facts and therefore give some suggestions to address future tourism policies of alpine destinations.

1. Mountain is still a tourist attraction for young people and adults, mainly thanks to its unique landscape and the sense of freedom offered by natural environment and by outdoor sport practice. People are mainly attracted to mountain landscape; however, today there's a strong competition on this "element" with other tourist destinations such as deserts and tropical islands. Since landscape and the environment are the most precious resources for alpine tourism, policy makers and stakeholders should carry on a critical reflection on the need to protect these "elements" and to develop sustainable practices.

2. It's been ages since people considered mountain areas severe, heavy and dangerous. Today young people see mountain as a place to live with friends and family and to do exciting but 
less strenuous sports and recreational activities. Adults are also interested in other elements such as cuisine, culture, well-being and shopping. The ways of enjoying mountain areas among young people are several and different compared to those in the past and they require less time and physical training than traditional alpine activities. Mountain is only the place where they can do sports and therefore there is no "sense of belonging".

3. Today the ways to enjoy mountain are various and involve new and different "elements" in addition to summer and winter outdoor activities. Young people still like alpine skiing; however, they practice occasionally. In summer the increasing popularity of Mountain Biking is likely to lead a more intensive use of ski lift for downhilling; on the other hand, snowshoeing allow a less intensive use during winter. This need to practice different sports and activities - which is expressed also by adults - should induce local policy makers and stakeholder to adjust their offer.

4. This lead to rethink alpine tourist offer - almost exclusively based on a single product - in small, medium and big resorts and begin to consider mountain areas as a space with a strong and multidimensional identity. Each single "dimension" should be enhanced in order to be offered at the highest level of quality, and become a part of a unique offer containing a wide range of products. This process can give new opportunities to smallest resorts: given the impossibility of competing with medium and big resorts in the diversity of services offered due to a lack of economic and human resources, these resorts can characterize their offer in a way that could allow them to differentiate themselves from the others (Unique Selling Proposition) and act as an enticement for the target they have chosen (young people, family, people living in the areas near the resorts, etc.). Therefore also the tourist offer in the entire destination can be larger, richer and more competitive.

5. The survey also highlights a crisis in associations, especially those concerning mountain such as Club Alpino Italiano, or simply the need to rethink their role. There are many volunteers that spend their time to pass down the culture of mountain (values, knowledge, etc.) but most of young people and their families are not interested in these associations and in their "sense of belonging". It would be important to understand whether people do not know the values of these associations - there would be therefore a lack of communication or they do not share them; however this is not the aim of this paper.

\section{BIBLIOGRAPHIE}

ASTAT, 2010.- Scialpinisti e ciaspolatori - Febbario 2010, ASTAT Info n³2, June 2010.

ATOUT FRANCE, 2011.- Carnet de route de la montagne, Éditions Atout France, Paris.

ATOUT FRANCE, 2012.- Panorama du tourisme de la montagne, Éditions Atout France, Paris.

BOURDEAU P., 1991.- « La montagne d'été et les politiques touristiques », Cahier d'Espace, n²5, pp. 64-70.

BOURDEAU P., 2007.- « L'or blanc : de l'épopée à la complexité », in Bourdeau, P.(eds), Les sports d'hiver en mutation, Lavoisier.

BOURDEAU P., 2008.- « Le post-tourisme comme grille de lecture du futur des Alpes ?», in HERAUSGENEBEN V., PASOLINI M., Le Alpi che cambiano, Retemontagna e Padova University Press. 
COFREMCA, 2000.- La montagne face aux évolutions des Clients et des Marchés, Rhone Alps-New Deal. CHHETRI P., ARROWSMITH C., JACKSON M., 2004.- « Determining hiking experiences in nature-based tourist destinations », in Tourism Management 25, p. 31-43.

DÉRIOZ P., BACHIMON P., 2010.- « Preface », in Revue de géographie alpine/Journal of Alpine Research [En ligne], 97-3.

DONDONA C. A., 2009.- « Escursionisti in Piemonte: chi sono, perché scelgono la nostra regione, quanto incidono sulla nostra economia », in Piemonte e Turismo. Scenari internazionali, trend dei mercati e prodotti turistici piemontesi, Regione Piemonte, p. 222-229.

FISI-Federazione Italiana Sport Invernali, 2011.- Gli italiani, la montagna e gli sport invernali. Principali evidenze delle tre ricerche condotte da AstraRicerche per FISI.

GODDE P.M., PRICE M.F., ZIMMERMANN F.M., 2000.- Tourism and Development in Mountain Regions, New York, CAB.

LYNN N.A., BROWN, R.D., 2003.- « Effects of recreational use impacts on hiking experiences in natural areas ", in Landscape and Urban Planning, ${ }^{\circ} 64$, p. 77-87.

MACCHIAVELli A., 2014.- « La montagna nel turismo italiano », in Becheri E., Maggiore G., (a cura di), Rapporto sul turismo italiano. XIX edizione, Franco Angeli, Milano, p. 371-386.

MARANGON F., RIZZI L., TEMPESTA T., VISINTIN F., 2002.- « Il valore ricreativo dei paesaggi forestali », in Rivista di Economia Agraria, LVII, nº, p. 637-680.

MARANGON F., GOTTARDO E., 2001.- « La valutazione monetaria del danno ai boschi del Friuli Venezia Giulia ", in Marangon F., Tempesta T. (a cura di), La valutazione dei beni ambientali come supporto alle decisioni pubbliche. Una riflessione alla luce della normativa comunitaria e nazionale, Forum Editrice Universitaria, Udine, p. 207-233.

MAтTо M., 2004.- Il ruolo dell'escursionismo nel rilancio del turismo montano. Il caso della Valle Maira, Grafica Santhiatese Editrice.

ODIT FRANCE, 2009.- Les chiffres clés du tourisme de montagne en France. $7^{\mathrm{e}}$ édition.

PICKERING C.M., ROSSI S., BARROS A., 2011.- « Assessing the impacts of mountain biking and hiking on subalpine grassland », Journal of Environmental Management, 92, p. 3049-3057.

PUTTILLI M., 2012.- Studiare le montagne. Itinerario della ricerca sulle terre alte piemontesi, Franco Angeli, Milano.

SALSA, A., 2010.- « Le Alpi, l'alpinismo e i valori universali », La Rivista, Bimestrale del CAI, gen-feb. SAINT-MARTIN J., SAVRE F., TERRET T., 2013.- « Les premiers rassemblements alpins de vélos tout terrain », Revue de géographie alpine/Journal of Alpine Research [En ligne], 100-3.

SCARPA R., THIENE M., TEMPESTA T., 2007.- « Latent class count models of total visitation demand : days out hiking in the eastern Alps », Environmental and Resource Economics, 38, pp. 447-460.

TEMPESTA T, THIENE M., 2001.- « Costi e benefici sociali dell'attività escursionistica ed alpinistica. Rapporto fra sentieristica e sicurezza degli escursionisti », Atti del Convegno « Sentieri al bivio ? ", Trento, 1st June.

TOSI V., SCRINZI G., 1994.- « Turismo nel Parco Naturale delle Dolomiti di Sesto (Bolzano) : un'analisi quali-quantitativa dell'utenza », ISAFA comunicazioni di ricerca, $\mathrm{n}^{\circ} 1$.

WARDE A., TAMPUBOLON G., 2002.- « Social capital, networks and leisure consumption », The Sociological Review, 50 (2), eScholarIDv. 


\section{NOTES}

1. ERSAF is the Agency for agriculture and forestry services in Lombardy.

2. VETTA stands for "Valorizzazione delle Esperienze e dei prodotti Turistici Transfrontalieri delle medie e delle Alte quote" ("Increasing the value of transboundary experiences and tourist products from medium-high mountain areas").

3. Computer-assisted telephone interviewing (CATI) is a telephone surveying technique in which the interviewer follows a script provided by a software application.

4. The regions considered in this survey have been Valle d'Aosta, Piemonte, Liguria, Lombardia, Emilia-Romagna, Veneto, Trentino Alto Adige and Friuli Venezia Giulia.

5. The provinces considered in this survey have specific features: the province of Milano is located in the plain; the province of Lecco is partly mountainous; the province of Sondrio is entirely mountainous.

6. Non-practitioners are those who usually go to mountain areas but do not practice any sports.

7. In this research 4 hours has been considered the minimum duration of a satisfactory walking.

8. http://www.mottolino.com/.

9. http://www.poolsciitalia.com/index.php/2012-09-24-15-04-51/mercato-sci-2012-13.

10. Many data and information collected couldn't have been presented in this paper.

\section{RÉSUMÉS}

The active frequentation of mountain areas has been analysed especially in relation with the territory and the landscape. This paper presents the results of an extensive research project carried out in Northern Italy that investigated the relationship between people and mountain focusing especially on younger generations, and highlights the conditions and the expectations towards mountain hiking in the Alps both in summer and winter. The analysis was carried out by: an overview of existing literature on the subject, with particular reference to Italy; a direct CATI survey on a population sample; a direct survey on a sample of students from high schools; in-depth interviews with guides from the Youth Mountaineering Commissions of Club Alpino Italiano (CAI). The paper will present a reasoned synthesis of the work done, with the aim to bring out the main factors that characterize the relationship between young people and mountain hiking.

\section{INDEX}

Keywords : hiking, young generation, mountain attraction

\section{AUTEURS}

\section{ANDREA MACCHIAVELLI}

University of Bergamo - CeSTIT (Centro Studi per il Turismo e l'Interpretazione del Territorio) 


\section{ANDREA POZZI}

University of Bergamo - CeSTIT (Centro Studi per il Turismo e l'Interpretazione del Territorio) 